\title{
Sumatran Pale Hedge Blue Udara dilecta neodilecta (Corbet, 1937) (Lepidoptera: Lycaenidae) in Kerinci Highlands, a southernmost record
}

\author{
Muhammad Iqbal $^{1 *}$, Arum Setiawan ${ }^{2}$, Indra Yustian ${ }^{3}$ \\ *email:kpbsos26@yahoo.com \\ ${ }^{1}$ Biology Program, Faculty of Science, Sriwijaya University, Jalan Padang Selasa 524, \\ Palembang, Sumatera Selatan 30129, Indonesia. \\ ${ }^{2,3}$ Department of Biology, Faculty of Science, Sriwijaya University. Jl. Raya Palembang- \\ Prabumulih $\mathrm{km}$ 32, Indralaya, Indonesia.
}

\begin{abstract}
Two tiny individuals of Sumatra Pale Hedge Blue Udara dilecta neodilecta (Fruhstorfer, 1910) were observed and documented on 18 August 2014 in Lake Kaco of Kerinci Highlands, Jambi Province. This butterfly was determined using appropriate guides. Finding of Udara d. neodilecta represent a southernmost record $\left(02^{0} \mathrm{~S}\right)$ for this Sumatran endemic subspecies in its range.
\end{abstract}

Keywords: Lycaeninae, range, record, Sumatra, Udara dilecta neodilecta.

\section{INTRODUCTION}

The blues butterflies or family Lycaenidae are a large family with a generally small-sized, delicate and often tailed wings (Kirton, 2014). Family Lycaenidae are of world wide distribution, being mainly tropical, but with many wellknown temperate species, some of which are considered minor pests of leguminous crops (Parsons, 1999). They are amongst the most beautiful butterflies with upperside of the wings is metallic blue or orange-red in most species; and iridescent blue, copper and green colour (Holloway et al., 2001).

Family Lycaenidae in Indonesian are divided into four subfamilies: Poritinae, Miletinae, Curetinae and Lycaeninae colour (Holloway et al., 2001). Subfamily Lycaeninae are delicate butterflies; and characteristic tail-tornal eyespot arrangement on the hindwing is wing's side of the butterfly allowing an opportunity for the butterfly to escape although without a less critical part of its wings (Khoon, 2010). This enormous subfamily, probably accounting for at least one-third of the true butterflies species, can be separated from the other lycaenid subfamilies in which males use the foreleg for walking by two principal characters (Corbet \& Pendlebury, 1992).

Udara are a large genus of subfamily Lycaeninae contains at least 40 species and occurs throughout the IndoAustralian region, from Srilangka, India, Southeast Asia, Japan, Indonesia, New Guinea, Solomon Islands and Australia (Parsons, 1999). They have small eyes and hairy, antennae slightly shorter or longer than the forewing cell and with a small patch of white scales near the tip of the club, forewing cell slightly longer than half the wing (Eliot \& Kawazoe, 1983). The Pale Hedge Blue Udara dilecta is one species of genus Udara which widely distributed, from Pakistan, India, China, Japan, Southeast Asia, Indonesia and Papua New Guinea (Eliot \& Kawazoe, 
1983). In Sumatra, the species represented by endemic subspecies, Udara dilecta neodilecta (Corbet, 1937). In this paper, we report the occurrence of $U$. dilecta neodilecta from Lake Kaco of Kerinci Highlands (Jambi Province), represent a new locality and southernmost record of this subspecies in the island (Eliot \& Kawazoe, 1983).

\section{MATERIALS AND METHODS}

On 18 August 2014, two individuals of tiny butterflies are found and documented in Lake Kaco of Kerinci Highlands, Lempur Village, Gunung Raya Subdistrict, Kerinci District, Jambi Province, Sumatra. Lake Kaco of Kerinci Highlands (02 $\left.20^{\prime} 31.85^{\prime \prime S}, 101^{\circ} 34^{\prime} 20.65^{\prime \prime E}\right)$ is located around $1.200 \mathrm{~m}$ above sea level. Refer to Whitten et al. (2000), this zone $(1.200$ to $2.100 \mathrm{~m})$ is classified as lower montane forest in Sumatra. Due to the limitation on permits and equipments, these tiny butterflies are unable to be caught and preserved as specimens. However, some characters are seen, and it is determined based on the specific morphological characters from photographs (Figure 1). These tiny butterflies are identified using appropriate references (eg. Eliot \& Kawazoe, 1983; Corbet \& Pendlebury, 1992; Parsons, 1999; Schroeder 2020).

\section{RESULTS AND DISCUSSIONS}

Two tiny butterflies found in Lake Kaco of Jambi Province are identified as Pale Blue or genus Udara dilecta by its tiny size and pale blue colour on upperside of forewings and hindwings. Both butterflies have pale blue in upperside wings, with the forewing border a thread and the hindwing lacking marginal spots; and on the underside, the markings are very limited (Figures 1 and 2). This species is very similar to Udara rona and Udara cardia. The two tiny pale butterflies from Lake Kaco of Jambi Province is eliminated from $U$. cardia by lacking darker spots in hindwing beneath; and unconsidered as $U$. rona because $U$. rona has a darker blue colour on upperside wings (Eliot \& Kawazoe, 1983; Corbet \& Pendlebury, 1992; Parsons, 1999; Schroeder 2020).

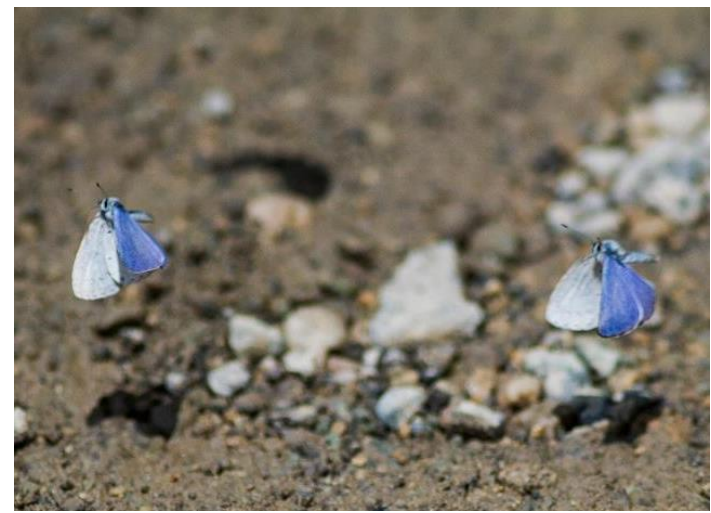

Figure 1. Two $U$. dilecta neodilecta found in Lake Kaco, Jambi Province, 18 August 2014 (@Reinaldo de Medeiros).

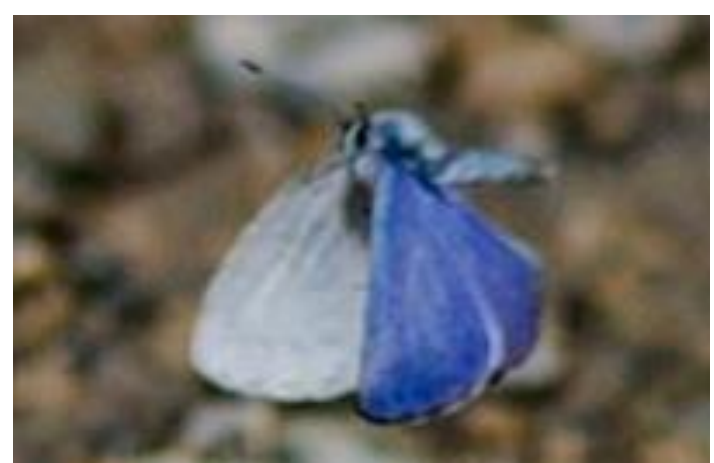

Figure 2. Close up of $U$. dilecta neodilecta found in Lake Kaco, Jambi Province, 18 August 2014 (@Reinaldo de Medeiros).

There are seven subspecies of $U$. dilecta: $U$. dilecta coalitoides (Rothschild, 1915), U. dilecta dilecta (Moore, 1879), $U$. dilecta neodilecta (Corbet, 1937), $U$. dilecta paracatius (Fruhstorfer, 1917), $U$. dilecta parva Eliot and Kawazoé, 1983, $U$. dilecta subcoalita (Rothschild, 1915) dan $U$. dilecta thoria (Fruhstorfer, 1910). U. $d$. catius (Fruhstorfer, 1910) and U. rona rona (Grose-Smith, 1894) (Eliot \& 
Kawazoe, 1983). The subspecies that occur in Sumatra is $U$. dilecta neodilecta or Sumatran Pale Hedge Blue, an endemic subspecies for the island (Eliot \& Kawazoe 1983, Corbet \& Pendlebury 1992). Records of $U$. dilecta neodilecta are very limited. In British Museum of Natural History (BMNH), there are two males ex Martin collection from the Batak Mountains (a group of mountains in North Sumatra, including Sibayak mountain, Sinabung Mountain and Sorik Merapi mountain), both without abdomens, which have been labeled as syntypes of neodilecta (Eliot \& Kawazoe, 1983). The other has no white patch on the forewing, and as it is the normal form in Sumatra designate as lectotype; it is labeled /Type [red]/ CMB x.94/neodilecta [in Fuhstorfer's hand]/. The other male, labeled /Type [red]/ CMB xi.93/catius fa. neodilecta Fr. [in Fuhstorfer's hand]/ is a paralectotype. Other following records of $U$. dilecta neodilecta are five male specimens collected on 23 February 1974 from Berastagi (altitude $02^{0} \mathrm{~N}$, North Sumatra Province), specimen collected from Harau Valley (altitude $00^{\circ} \mathrm{S}$, West Sumatra Province) without date information, and 23 individuals encountered during September to November 2013 in Sago Mountain (altitude $00^{\circ} \mathrm{S}$, West Sumatra Province) (Rusman et al., 2016; Teshirogi et al., 2016; Schroeder 2020). Record of $U$. dilecta neodilecta from Lake Kaco of Kerinci Highlands (altitude $02^{0} \mathrm{~S}$, Jambi Province) represent a southernmost record of this subspecies in Sumatra (see Figure 3). All localities where $U$. dilecta neodilecta found in Sumatra are found c. $1.200 \mathrm{~m}$ above sea level. Corbet \& Pendlebury (1992) reported $U$. dilecta as one of three species of Udara usually found at elevations above 2.000 feet or around $600 \mathrm{~m}$ above sea level.

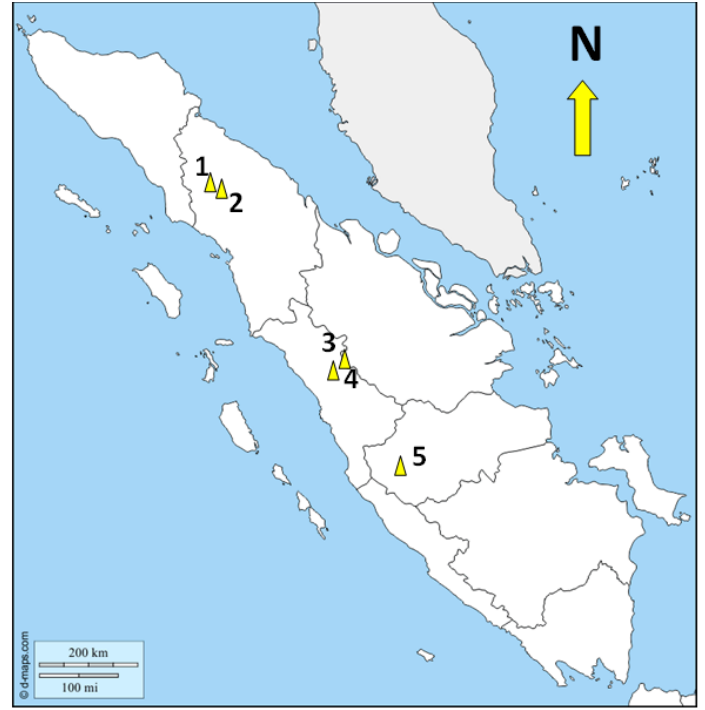

Figure 3. Locations of $U$. dilecta neodilecta recorded in Sumatra: 1. Batak Mountains; 2. Berastagi; 3. Harau Valley; 4. Sago Mountain; 5. Lake Kaco.

There is no information previously reported on host plants of $U$. dilecta (Eliot \& Kawazoe, 1983; Corbet \& Pendlebury, 1992; Robinson et al., 2001), but based on vegetation survey conducted in Sumatran Highlands and combine to summarized host plants of genus Udara, potential host plants of $U$. dilecta in Sumatra are Fagaceae (Quercus subsericea, Castanopsis sp. and Lithocarpus sp.) and Euphorbiaceae (Phyllanthus sp., Macaranga sp., Endospermum sp., Cleoxylon sp., Croton sp. and Aporosa sp.) (Robinson et al., 2001; Pragustiandi, 2020).

The occurrence of $U$. dilecta neodilecta in Lake Kaco of Kerinci Highlands suggests the importance of lower mountain forests in Sumatra as a habitat of endemic species and subspecies butterflies. The recent reports of Dempo Paris Peacock Papilio paris dempo and Hagen's batwing Atrophaneura hageni in lower mountain forests in southern Sumatra justify that spatial distribution of some endemic species and subspecies butterflies still lacking (Iqbal et al., 2020; Setiawan et al., 2020). More studies are 
required to learn a better understanding about butterflies diversity in Sumatra.

\section{CONCLUSIONS}

Two tiny individuals of Sumatra Pale Hedge Blue Udara dilecta neodilecta (Fruhstorfer, 1910) were sighted and documented on 18 August 2014 in Lake Kaco of Kerinci Highlands, Jambi Province. This record represent a southernmost record $\left(02^{0} \mathrm{~S}\right)$ of this endemic subspecies in Sumatra.

\section{Acknowledgements}

We are very grateful to Reinaldo de Medeiros (Universidade Veiga de Almerda, Brazil) for sharing his photo and information regarding Sumatra Pale Hedge Blue in Kerinci Highlands. We thank reviewers who give their valuable comments for this paper.

\section{REFERENCES}

Corbet., A. S. (1937). A revision of the Malayan species of Celastrina (Lepidoptera: Lycaenidae).

Transactions of the Entomological Society of London, 86: 19-34

Corbet, A. S., \& H.M. Pendlebury, H. M. (1992). The Butterflies of the Malay Peninsula (4th ed.). Kuala Lumpur: Malayan Nature Society.

Eliot, J. N. (1973). The higher classification of the Lycaenidae (Lepidoptera): $\quad$ a tentative arrangement. Bulletin of the British Museum Natural History Entomology, 28(6): 373-505.

Eliot, J.N., \& A. Kawazoe. (1983). Blue butterflies of the Lycaenopsis group. Hampshire: British Museum Natural History.

Holloway, J. D., Kibb, G., \& Peggie, D. (2001). The Families of Malesian Moths and Butterflies. Leiden: Brill.
Iqbal, M., Aprillia, I., Saputra, R. F., Pormansyah., Pragustiandi, G., Setiawan, A., \& Yustian, I. (2020). Dempo Paris Peacock Papilio paris dempo Okano, 1988 (Lepidoptera: Papilionidae) Revisited. Sainmatika, 17(1): 31-35.

Khoon, S. K. (2010). A field guide to the butterflies of Singapore. Singapore: Ink On Paper Communications Pte Ltd.

Parsons, M. (1999). The Butterflies of Papua New Guinea, Their systematics and Biology. San Diego: Academic Press.

Pragustiandi, G. (2020). Spesies Prioritas Untuk Konservasi Tumbuhan di Wilayah Kerja PT. Supreme Energi Rantau Dedap Kawasan Hutan Lindung Bukit Jambul Gunung Patah Provinsi Sumatera Selatan. Thesis, Jurusan Biologi Konservasi,. Fakultas Matematika dan Iimu Pengetahuan Alam. Universitas Sriwijaya [in Indonesian].

Robinson, G. S., Ackery, P. R, I.J. Kitching, I. J., Beccaloni, G. W., \& Hernandez, L. M. (2001). Hostplants of the Moth and Butterfly Caterpillars of the Oriental Region. London: The Natural History Museum.

Rusman, R., Atmowidi., T., \& Peggie, D. (2016). Butterflies (Lepidoptera: Papilionoidea) of Mount Sago,West Sumatra: Diversity and Flower Preference. Hayati Journal of Biosciences, 23: 132-137.

Schroeder, S. 2020. Tropical Lycaenidae. Retrieved August 20, 2020, from http://tropical-lycaenidae.net/tropicallycaenidae/lycaenopsis/udara/.

Setiawan, D., Aprillia, I., Iqbal, M., Pragustiandi. G., Setiawan, A., \& Yustian, I. (2020). First record of Hagen's batwing Atrophaneura hageni (Rogenhofer, 1889) (Lepidoptera: Papiolinidae) in southern Sumatra, Indonesia. Ecologica Montenegrina, 28: 26-30. 
Teshirogi, M., Harada, M., Ito, H., Harada, K., Tanio, T., Ito, Y., \& Yago, M. (2016). Catalogue of the Suguru Igarashi Insect Collection, The University Museum, The University of Tokyo. Part IV. Lepidoptera: Lycaenidae \& Riodinidae. Retrieved August 20, 2020, from http://umdb.um.utokyo.ac.jp/DDoubutu/Igarashi04/en/ result.php?skip $=0 \& \max =50 \&$ keywor $\mathrm{d}=$ Udara+dilecta.

Whiten, T., Damanik, S. J., Anwar, J., \& Hisyam, N. (2000). The ecology of Sumatra. Singapore: Periplus. 